\title{
Pollution levels of stormwater discharges and resulting environmental impacts
}

Brudler, Sarah; Rygaard, Martin; Arnbjerg-Nielsen, Karsten; Hauschild, Michael Zwicky; Ammitsøe, Christian; Vezzaro, Luca

Published in:

Science of the Total Environment

Link to article, DOI:

10.1016/j.scitotenv.2019.01.388

Publication date:

2019

Document Version

Peer reviewed version

Link back to DTU Orbit

Citation (APA):

Brudler, S., Rygaard, M., Arnbjerg-Nielsen, K., Hauschild, M. Z., Ammitsøe, C., \& Vezzaro, L. (2019). Pollution levels of stormwater discharges and resulting environmental impacts. Science of the Total Environment, 663, 754-763. https://doi.org/10.1016/j.scitotenv.2019.01.388

\section{General rights}

Copyright and moral rights for the publications made accessible in the public portal are retained by the authors and/or other copyright owners and it is a condition of accessing publications that users recognise and abide by the legal requirements associated with these rights.

- Users may download and print one copy of any publication from the public portal for the purpose of private study or research.

- You may not further distribute the material or use it for any profit-making activity or commercial gain

- You may freely distribute the URL identifying the publication in the public portal 


\section{Accepted Manuscript}

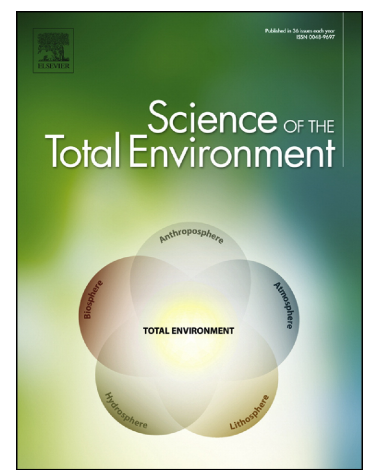

Sarah Brudler, Martin Rygaard, Karsten Arnbjerg-Nielsen, Michael Zwicky Hauschild, Christian Ammitsøe, Luca Vezzaro

Pollution levels of stormwater discharges and resulting environmental impacts

PII: S0048-9697(19)30436-X

DOI: https://doi.org/10.1016/j.scitotenv.2019.01.388

Reference: STOTEN 30702

To appear in: Science of the Total Environment

Received date: 28 August 2018

Revised date: 28 January 2019

Accepted date:

29 January 2019

Please cite this article as: S. Brudler, M. Rygaard, K. Arnbjerg-Nielsen, et al., Pollution levels of stormwater discharges and resulting environmental impacts, Science of the Total Environment, https://doi.org/10.1016/j.scitotenv.2019.01.388

This is a PDF file of an unedited manuscript that has been accepted for publication. As a service to our customers we are providing this early version of the manuscript. The manuscript will undergo copyediting, typesetting, and review of the resulting proof before it is published in its final form. Please note that during the production process errors may be discovered which could affect the content, and all legal disclaimers that apply to the journal pertain. 


\section{Pollution levels of stormwater discharges and resulting environmental impacts}

Sarah Brudler a, b, *, Martin Rygaard a, Karsten Arnbjerg-Nielsen a, Michael Zwicky Hauschild c, Christian Ammitsøe $^{d}$ Luca Vezzaro $^{a}$

a Urban Water Systems, Department of Environmental Engineering, Technical University of Denmark, Denmark

b VCS Denmark, Denmark

c Quantitative Sustainability Assessment, Department of Management Engineering, Technical University of Denmark, Denmark

d HOFOR, Denmark

*Corresponding author: sabr@env.dtu.dk

\section{Graphical abstract}

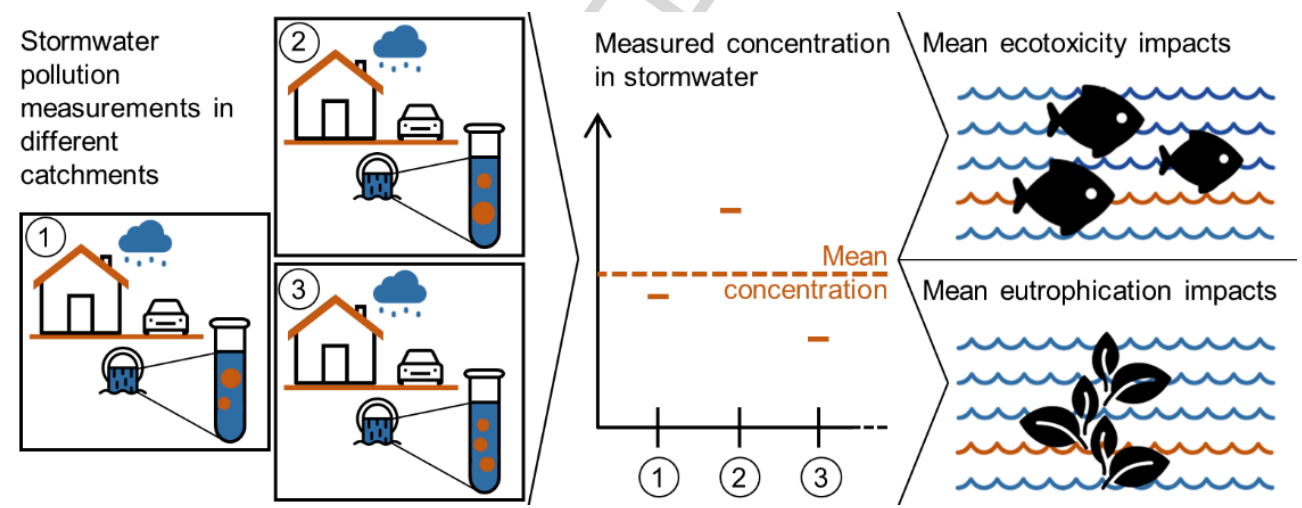

Highlights

- Concentration data for more than 300 pollutants in stormwater is collected

- Mean concentrations of metals, organic compounds and nutrients are calculated 
- Stormwater discharges may cause significant ecotoxicity impacts

- Metals cause the main share of ecotoxicity impacts

- Eutrophication impacts are less significant than ecotoxicity impacts

\section{Abstract}

Stormwater carries pollutants that potentially cause negative environmental impacts to receiving water bodies, which can be quantified using life cycle impact assessment (LCIA). We compiled a list of 20 metals, almost 300 organic compounds, and nutrients potentially present in stormwater, and measured concentrations reported in literature. We calculated mean pollutant concentrations, which we then translated to generic impacts per litre of stormwater discharged, using existing LCIA characterisation factors. Freshwater and marine ecotoxicity impacts were found to be within the same order of magnitude $(0.72$, and $0.82 \mathrm{CTUe} / \mathrm{l}$ respectively), while eutrophication impacts were $3.2 \mathrm{E}-07 \mathrm{kgP}-\mathrm{eq} / \mathrm{l}$ for freshwater and $2.0 \mathrm{E}-06$ $\mathrm{kgN}$-eq/l for marine waters. Stormwater discharges potentially have a strong contribution to ecotoxicity impacts compared to other human activities, such as human water consumption and agriculture. Conversely, contribution to aquatic eutrophication impacts was modest. Metals were identified as the main contributor to ecotoxicity impacts, causing more than $97 \%$ of the total impacts. This is in line with conclusions from a legal screening, where metals showed to be problematic when comparing measured concentrations against existing environmental quality standards.

Life cycle impact assessment; Ecotoxicity; Eutrophication; Metals; Organics; EQS

\section{Introduction}

Stormwater from impervious urban areas, such as roads, roofs, and parking lots, contains a wide range of pollutants that have the potential to cause negative environmental impacts when discharged to surface waters. These pollutants stem from human activities (e.g. accidents and dispersion of chemicals), wearing of road materials and vehicles (e.g. brakes, tires), and leaching from construction materials (corrosion of metallic roof, leaching of biocides from plastic, etc.) (Eriksson et al., 2005). Several studies have measured pollutant levels in urban stormwater (Gasperi et al., 2014a; Zgheib et al., 2012), quantified their toxic effect 
(Pohl et al., 2015; Tang et al., 2013; Wium-Andersen et al., 2011), and prioritized them according to the risk they pose to the aquatic environment (Eriksson et al., 2007; Gosset et al., 2017). At the same time, new strategies for managing stormwater in urban areas have been proposed (Fletcher et al., 2014). Since urban water managers have to decide between different management options, assessing the environmental impacts of the potential solutions can provide valuable information to support decision making.

Traditionally, stormwater discharges are assessed using risk assessment (e.g. Eriksson et al., 2007; Gosset et al., 2017). The expected maximum pollutant concentrations in the water environment are compared with toxicological threshold concentrations (obtained from results of toxicity tests) to assess the potential risk posed by discharge of stormwater. Risk assessment is usually chosen to analyse extreme and worst case scenarios, with a main focus on safety (IEC, 2009), i.e. limiting the risk of experiencing negative effects on the health of humans and ecosystems caused by short-term exposure to substances after intermittent discharges.

In contrast, life cycle assessment (LCA) focuses on effects resulting from exposure of ecosystems over longer time scales (years). LCA is an internationally standardized method to holistically quantify potential impacts of products and technical systems over their full life cycle (ISO, 2006a, 2006b), enabling the comparison of different management options based on contributions to a widely encompassing range of environmental impacts. The use of LCA to assess urban water systems has been increasing, but local emissions of pollutants from intermittent discharges of stormwater challenge the global perspective applied in LCA and are usually neglected (Brudler et al., 2016; De Sousa et al., 2012; Loubet et al., 2015; Spatari et al., 2011). Impacts resulting from stormwater discharges have recently gained attention: Risch et al. (2018), for example, showed that stormwater discharges cause significant environmental impacts compared to discharges of treated effluents in Paris. 
(a) In the field

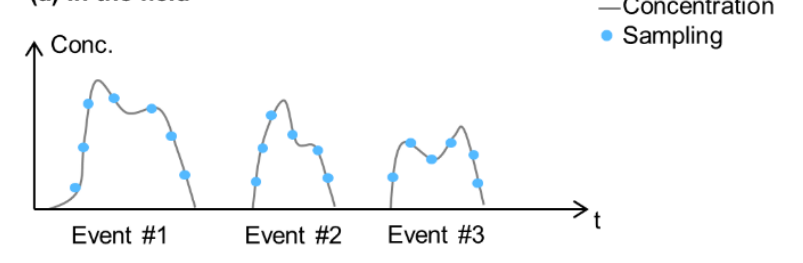

(b) In the laboratory

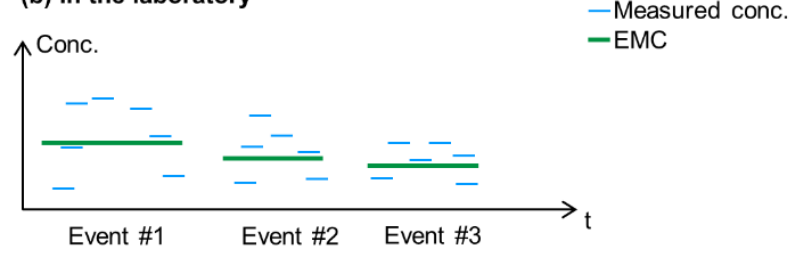

(c) In literature

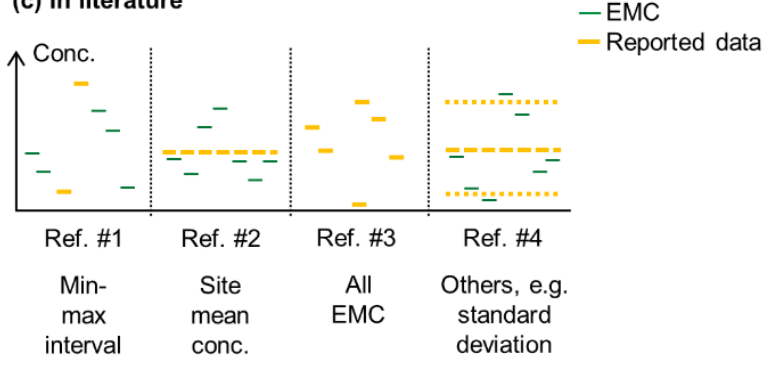

(d) Assessing environmental impacts

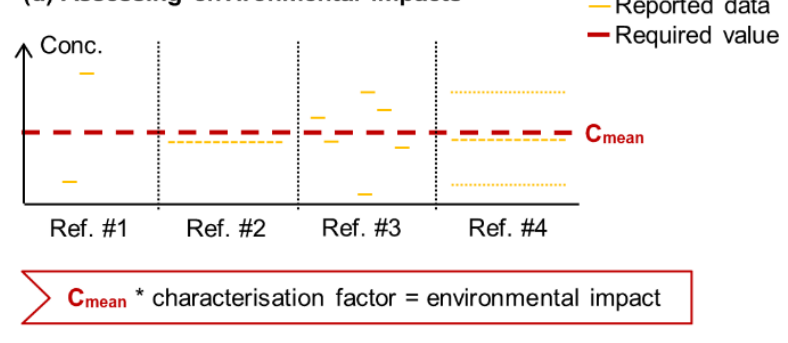

Figure 1. Conceptual scheme of the information flow of stormwater quality measurements for one exemplary substance. (a) Urban runoff is sampled during different rain events and (b) the collected samples are analysed and event mean concentrations (EMC) are calculated. (c) EMC for specific sites are reported in literature in different formats. (d) Life cycle impact assessment requires the estimation of a mean concentration, based on which environmental impacts are calculated using existing characterisation factors.

Within LCA, the life cycle impact assessment (LCIA) translates an inventory of emissions to environmental impacts (ISO, 2006b). For stormwater discharges, these emissions can be determined by the concentration of pollutants in stormwater. In fact, analyses of large concentration datasets have shown a correlation between event loads and discharged volumes (e.g. Métadier and Bertrand-Krajewski, 2012). This allows for estimating yearly pollutant discharges by applying the simple volume-concentration method (e.g. Park et al., 2009).

Available measurements of pollution levels in stormwater are inherently characterized by high spatial and temporal variability both within the same rain event and between different events (Figure 1a,b). Such variability is caused by the various pollutant sources across urban catchments and by the highly dynamic pollutant release and transport processes. Monitoring of stormwater is also characterized by several inherent sources of uncertainty (Bertrand-Krajewski, 2007). All these factors contribute to the high heterogeneity of the available data (Figure 1c), which also differ in terms of sampling approaches, measurement methodologies, and reporting style (Göbel et al., 2007). Since LCA operates on total pollutant flows, it 
requires the estimation of mean pollution levels over long exposure periods, and the characteristics of the available data thus pose a serious challenge and require additional data elaboration (Figure 1d). When a sufficient number of consistent measurements is available, average pollutant concentrations can be estimated based on their known statistical distribution (Van Buren et al., 1997). However, this is rarely the case when looking at stormwater micropollutants. Attempts have been made to obtain a "representative, average concentration" (Göbel et al., 2007), but little attention has been given to the characteristic of the reported data in those calculations.

The main goal of this study was to evaluate the long-term environmental impacts of stormwater discharges, and to identify the most problematic pollutants in stormwater. This assessment required several steps:

- quantifying levels of stormwater pollution based on the available literature data,

- performing LCIA of stormwater discharges using the estimated pollution levels

- evaluating the relative contribution of single pollutants to the total environmental impacts

- comparing the impacts from stormwater to impacts from other relevant sources

Furthermore, we related the concentration data to existing environmental quality standards. We then compared the conclusions regarding problematic substances, drawn from both LCIA and the legal screening, in order to identify potential shortcomings.

\section{Methods and data}

\subsection{Available data for pollutants in stormwater}

Information on stormwater pollutants was obtained from reports of measurement campaigns, previous reviews and data elaborations, and databases from Europe and the US (Table 1). A total of 25 publications were identified as relevant, providing data from more than hundred sites and thousands of events from both European and North-America (Table 1). References using units inconsistently or stating only extreme values (e.g. in runoff from heavy industry or waste disposal sites) were not considered. No differentiation between source types (roofs, roads, etc.) was attempted as data were insufficient to calculate specific averages. 
Since the aim was to quantify the contributors to and relevance of impacts from stormwater discharges, a catchment specific assessment lies outside the scope of this paper. Also, available data suggested that variations in concentration levels between standard urban catchments were small compared to the variation between different events at a particular location (Arnbjerg-Nielsen et al., 1999; Zgheib et al., 2012). The uncertainty in the estimation of an average concentration for a specific site can be estimated based on the number of available measurements and on the inherent variability of the measured pollutant (BertrandKrajewski et al., 2002). 
Table 1. References used to compile a list of pollutants potentially present in runoff, scope (as number of sampled catchments and events) and reported concentration data. $\mathrm{EMC}=$ event mean concentration, $\mathrm{SD}=$ standard deviation. ${ }^{*}$ Concentration data available in reference, but not used in analysis, e.g. due to aggregation into substance groups in reference.

\begin{tabular}{|c|c|c|c|c|c|c|c|c|}
\hline \multirow[t]{2}{*}{ Reference type } & \multirow[t]{2}{*}{ Region } & \multicolumn{2}{|c|}{ Scope [\#] } & \multirow[t]{2}{*}{ Reported concentration data } & \multirow[t]{2}{*}{ Metals } & \multirow[t]{2}{*}{ Organic comp. } & \multirow[t]{2}{*}{ Nutrients } & \multirow[t]{2}{*}{ Reference } \\
\hline & & Catchments & Events & & & & & \\
\hline \multirow{20}{*}{$\begin{array}{l}\text { Measurement } \\
\text { campaigns }\end{array}$} & Denmark & 2 & $1.5 \mathrm{yrs}$ & Maximum & - & $\mathrm{X}$ & - & (Asman et al., 2005) \\
\hline & Denmark & 4 & 4 & EMC & $x$ & $x$ & - & (Birch et al., 2011) \\
\hline & Denmark & & & & - & $X^{*}$ & $x$ & $\begin{array}{c}\text { (Clauson-Kaas et al., } \\
2016)\end{array}$ \\
\hline & Denmark & 1 & 9 & Site mean, range & $X^{*}$ & & $x$ & $\begin{array}{c}\text { (Environmental Protection } \\
\text { Agency Denmark, 2006) }\end{array}$ \\
\hline & Denmark & 2 & 6 & Site average, SD & $\mathrm{x}$ & $x$ & $x$ & (Kjøholt et al., 1997) \\
\hline & Denmark & 2 & 2 & EMC & $x$ & $x$ & $\mathrm{x}$ & (Kjølholt et al., 2001) \\
\hline & Denmark & 1 & 1 & EMC & $x$ & $x$ & - & (Lützhøft et al., 2011) \\
\hline & Denmark & 3 & 1 & EMC & $X^{*}$ & $x$ & $X^{*}$ & $\begin{array}{l}\text { (Madsen and Nielsen, } \\
\text { 2008) }\end{array}$ \\
\hline & Denmark & 1 & 3 & EMC & $X^{*}$ & $\mathrm{x}$ & $X^{*}$ & (Pedersen et al., 2009) \\
\hline & Denmark & 2 & 3 & EMC & $X^{*}$ & $x$ & $X^{*}$ & (Pedersen, 2013) \\
\hline & Denmark & 1 & 15 & EMC & $X^{*}$ & $x$ & $X^{*}$ & (Ørestad, n.d.) \\
\hline & France & 3 & $7-24$ & Mean, SD, conf. interval & $x$ & $x$ & - & (Gasperi et al., 2014a) \\
\hline & France & 2 & 12 & EMC, confidence interval & $x$ & $X^{*}$ & - & $\begin{array}{c}\text { (Becouze-Lareure et al., } \\
\text { 2016) }\end{array}$ \\
\hline & France & 1 & 15 & Site median, range & $\mathrm{x}$ & $\mathrm{x}$ & - & (Sebastian, 2013) \\
\hline & France & 3 & 16 & Median, range & $x$ & $x$ & $\mathrm{X}^{*}$ & (Zgheib et al., 2012) \\
\hline & Sweden & 1 & 1 & EMC & - & $x$ & - & (Näf et al., 1990) \\
\hline & Germany & 6 & & Average, maximum, SD & $x$ & $x$ & $x$ & (Wicke et al., 2015) \\
\hline & Austria & 2 & 4 & EMC & - & $x$ & - & (Clara et al., 2010) \\
\hline & California, US & 34 & 3 & Mean, median, range, SD & $x$ & - & $X^{\star}$ & (Kayhanian et al., 2007) \\
\hline & California, US & 1 & 1 & Mean, median, range & - & $\mathrm{x}$ & - & (Wenning et al., 1999) \\
\hline \multirow[t]{2}{*}{ Reviews } & Denmark & & & Range & $\mathrm{X}$ & $\mathrm{X}$ & $\mathrm{X}^{*}$ & $\begin{array}{l}\text { (Arnbjerg-Nielsen et al., } \\
\text { 2002) }\end{array}$ \\
\hline & Europe & & & Range & $x$ & - & $x$ & $\begin{array}{l}\text { (European Commission, } \\
\text { 2002) }\end{array}$ \\
\hline \multirow[t]{2}{*}{ Databases } & Denmark & 17 & 46 & EMC & $\mathrm{X}$ & $\mathrm{X}^{*}$ & $\mathrm{X}^{*}$ & (GEUS, n.d.) \\
\hline & United States & $>100$ & $>8,500$ & Median, average, SD, range & $x$ & $\mathrm{X}^{*}$ & $\mathrm{X}^{*}$ & (US EPA, 2015) \\
\hline \multirow[t]{4}{*}{$\begin{array}{l}\text { Legislation / } \\
\text { guidelines }\end{array}$} & Denmark & & & & & & & $\begin{array}{c}\text { (Danish Nature Agency, } \\
2016)\end{array}$ \\
\hline & Denmark & & & Ne concontration & & & & (Kjølholt et al., 2007) \\
\hline & Europe & & & No concentration o & & & & $\begin{array}{l}\text { (European Commission, } \\
2000)\end{array}$ \\
\hline & Generic & & & & & & & (Ingvertsen et al., 2011) \\
\hline
\end{tabular}

Concentration data from Ledin et al. (2004) and Petersen et al. (2013) were taken into consideration, but not included due to inconsistencies in the reported values. 


\subsection{Defining mean concentrations}

To calculate the average pollutant concentrations needed for calculation of total emissions required as the basis for the LCIA, different methods were applied, chosen according to data availability and pollutant characteristics:

- The median of all available measurements (as in Göbel et al. (2007)) was used when a sufficient number of data was available, as is the case for total phosphorous and nitrogen (assumed to cover the whole nutrient content);

- The triple estimate approach (Lichtenberg, 2000) was used for pollutants with limited data availability and expected high relevance for toxicity impacts, such as 18 metals and metalloids ( $\mathrm{Ag}, \mathrm{As}, \mathrm{Ba}, \mathrm{Be}$, $\mathrm{Cd}, \mathrm{Cr}, \mathrm{Cu}, \mathrm{Hg}, \mathrm{Mg}, \mathrm{Mo}, \mathrm{Ni}, \mathrm{Pb}, \mathrm{Se}, \mathrm{Sr}, \mathrm{Tl}, \mathrm{V}, \mathrm{Zn})$;

- The truly dissolved fraction of a metal was estimated and used if the mean concentration calculated with the triple estimate approach exceeded the solubility, which applied for two of the metals (Al, Fe);

- The uncorrected maximum concentrations were used to compensate for very limited concentration data availability (as in the case for most organic compounds). This is a worst-case approach.

\subsubsection{Triple estimate approach}

The triple estimate approach requires defining for each pollutant a minimum and maximum concentration, representing the $1 \%$ and $99 \%$ limits respectively, and a best guess (Lichtenberg, 2000). Assuming that data follow a skewed distribution, the mean concentration $\left(C_{\text {mean,i }}\right)$ was calculated using the following formula:(Lichtenberg, 2000)

$$
C_{\text {mean }, i} \approx \frac{C_{m i n, i}+3 * C_{B G, i}+C_{\max , \mathrm{corr}, i}}{5}
$$

The best guess $\left(C_{B G, i}\right)$ was calculated as the median of reported concentrations in four key references (Gasperi et al., 2014b; Sebastian, 2013; Wicke et al., 2015; Zgheib et al., 2012). These were selected due to their scope and detailed methodology description based on an expert judgement which looked at the scope of the references, the used protocols for collection, storage, and analysis of the samples, and the level of reported measurements (e.g. if all datasets were available in supporting information). If no data was available in the key references, the median value of measurements available in a large Danish database of 
stormwater pollutants (GEUS, n.d.) was used. The minimum concentration $\left(C_{\min , i}\right)$ was determined by the lowest value found in any of the available references. To remove extremely high values which showed great deviations from average values, the following formula was used:

$$
C_{\text {max }, \text { corr }, i}=\left\{\begin{array}{l}
C_{\max , i} \text { if } C_{\max , i} \leq 3 C_{B G, i} \\
3 C_{B G, i} \text { if } C_{\max , i}>3 C_{B G, i}
\end{array}\right.
$$

Where $C_{\text {max,corr, } i}$ is the corrected maximum concentration, and $C_{\text {max }, i}$ is the highest concentration found in literature.

\subsubsection{Truly dissolved fraction}

Only the truly dissolved fraction of a metal (representing the sum of the concentrations of free ion and inorganic complexes and excluding organic complexes) is considered bioavailable and hence potentially toxic (Diamond et al., 2010). If reported total concentrations exceeded maximum possible dissolved concentrations $\left(C_{\max , d i s s, i}\right)$, they were therefore corrected using the following formula for trivalent metals:

$$
C_{i}=\left\{\begin{array}{l}
C_{\text {max }, \text { diss }, i} \text { if } C_{\text {max }, \text { diss }, i}<C_{\text {mean }, i} \\
C_{\text {mean }, i} \quad \text { if } C_{\text {max }, \text { diss }, i} \geq C_{\text {mean }, i}
\end{array} \text { where } C_{\text {max }, \text { diss }, i}=\frac{K_{s p, i}}{\left[O H^{-}\right]^{3}} * M M_{i}\right.
$$

Where $K_{s p, i}$ is the solubility product constant for metals forming insoluble hydroxide compounds, and $M M_{i}$ is the metal's molar mass. An average pH of 7 was assumed for stormwater (Zgheib et al., 2012; US EPA, 2015). Dissolved metal concentrations may exceed this theoretical maximum concentration if organic ligands are present to form complexes, shielding the metal ions from precipitation, but the complex-bound metal species are not part of the truly dissolved fraction and hence not bioavailable and not considered toxic (Campbell, 1995).

\subsection{Life Cycle Impact Assessment}

Using LCIA, we calculated the generic impact of one litre of stormwater discharged to different environmental compartments based on the calculated mean concentrations. If a full LCA is conducted, i.e. a specific catchment is assessed, site-specific impacts from stormwater discharges can be calculated by multiplying the generic impact of one litre with the total stormwater volume from a given catchment (Brudler et al. 2018). Stormwater harvesting for human consumption always requires treatment, and direct human exposure to 
stormwater is normally very limited. If stormwater is discharged to receiving water bodies used for recreational activities, e.g. swimming, dilution and the short time span of exposure is expected to prevent critical effects on humans. We therefore did not consider human health impacts resulting from toxicity and pathogen exposure.

\subsubsection{Ecotoxicity impacts}

Ecotoxicity impacts were quantified using existing characterisation factors (CF) for discharges of pollutants to freshwater (Rosenbaum et al., 2008) and marine water (Dong et al., 2017). To avoid double counting, we only considered impacts occurring in the first compartment reached by the pollutant, and not subsequent impacts such as when runoff is discharged to a stream (freshwater) and subsequently reaches the sea (marine). The impacts are expressed in comparative toxicity units (CTUe), which represent the potentially affected fraction of freshwater species, integrated over time and volume (Henderson et al., 2011).

The freshwater ecotoxicity impact of pollutant $i, l_{\text {ecotox }, i}$, for one litre of stormwater was calculated as:

$$
I_{\text {ecotox }, i}\left\{\begin{array}{lr}
C F_{i} C_{i} V & \text { where } C F \text { is available for individual pollutant } i \\
\text { median }\left(C F_{m}\right) C_{i} V & \text { where } C F \text { is available for a class of pollutants, } m
\end{array}\right.
$$

Where $C_{i}$ is the mean concentration, $C F_{i}$ is the corresponding $C F$, and $V$ is the normalization volume of one litre. For a pollutant without a CF reported in the literature, a proxy CF was found by assigning it to a class of similar pollutants $m$ and using the median of the CFs available for this class.

CFs for freshwater ecotoxicity were available for all 20 metals, and marine ecotoxicity CFs for seven $(\mathrm{Cd}, \mathrm{Cr}, \mathrm{Cu}, \mathrm{Pb}, \mathrm{Mg}, \mathrm{Ni}, \mathrm{Zn}$ ). For organic compounds, only freshwater ecotoxicity impacts could be calculated, as CFs for marine ecotoxicity were not available. Freshwater ecotoxicity CFs were specified for 163 of the 286 organic compounds potentially present in runoff, which were used to calculate median CFs for seven substance classes. Impacts were calculated for 88 organic compounds with both concentration data and CFs available, and 57 compounds with only concentration data available (Table 2). The development of new CFs for pollutants would require significant data collection and measurements, which lies outside the scope of this paper. 
Table 2. Number of organic compounds named in literature and with freshwater ecotoxicity characterisation factor (CF) and / or concentration data available, and median CF and impact of seven pollutant classes. *The median CF of all organic compounds was used for unclassified pollutants.

\begin{tabular}{|c|c|c|c|c|c|c|}
\hline & $\begin{array}{l}\text { Named in } \\
\text { literature [\#] }\end{array}$ & $\begin{array}{c}\text { CF } \\
\text { available [\#] }\end{array}$ & $\begin{array}{l}\text { Conc. data } \\
\text { available [\#] }\end{array}$ & $\begin{array}{l}\text { CF and conc. data } \\
\text { available [\#] }\end{array}$ & $\begin{array}{c}\text { Median CF } \\
{[\text { CTUe/kg } \text { emitted }]}\end{array}$ & $\begin{array}{l}\text { Impact } \\
\text { [CTUe/l] }\end{array}$ \\
\hline $\mathrm{PAHs}$ & 33 & 13 & 25 & 12 & $6.1 \mathrm{E}+03$ & $4.8 \mathrm{E}-03$ \\
\hline Other hydrocarbons & 30 & 24 & 10 & 6 & $4.7 \mathrm{E}+02$ & $5.7 \mathrm{E}-06$ \\
\hline Other oil components & 6 & 6 & 6 & 6 & $1.3 \mathrm{E}+02$ & 8.7E-07 \\
\hline Dioxins & 15 & 5 & 11 & 3 & $9.0 \mathrm{E}+04$ & $8.7 \mathrm{E}-03$ \\
\hline Pesticides & 105 & 67 & 63 & 45 & $5.6 \mathrm{E}+04$ & $7.2 \mathrm{E}-03$ \\
\hline Phthalates & 18 & 12 & 12 & 10 & $3.7 \mathrm{E}+02$ & 4.2E-05 \\
\hline Phenols & 33 & 18 & 21 & & $5.4 \mathrm{E}+03$ & $3.6 \mathrm{E}-04$ \\
\hline Other org. compounds & 46 & 18 & 8 & & $-{ }^{*}$ & $7.0 \mathrm{E}-06$ \\
\hline All org. compounds & 286 & 163 & 156 & 96 & $2.9 \mathrm{E}+03$ & 2.1E-02 \\
\hline
\end{tabular}

\subsubsection{Eutrophication impacts}

Phosphorus is generally the limiting nutrient for algal growth in freshwater systems and thus causes potential eutrophication impacts (expressed in $\mathrm{kgP}-\mathrm{eq}$ ) when emitted to freshwater. Nitrogen is generally growth-limiting in marine water systems, and nitrogen therefore causes potential eutrophication impacts (expressed in $\mathrm{kgN}$-eq) when emitted to coastal waters. The nutrient mass corresponds directly to the impact without using a CF (Henderson, 2015). Consequently, the eutrophication of nutrient $k$, leutrop, $k$, was calculated as:

$$
I_{\text {eutrop, },}=C_{k} V
$$

Where $C_{k}$ is the median concentration of nutrient $k$, and $V$ is the normalization volume of one litre.

\subsubsection{Uncertainty analysis}

The data processing described in section 2.2 represents a source of uncertainty in the calculation of ecotoxicity impacts. The importance of this uncertainty was quantified by testing five alternative concentration scenarios:

- Triple estimate, corrected for dissolution (TE-diss): As some references state total concentrations and only dissolved metals are relevant for ecotoxicity impacts, $C_{\text {mean,i }}$ for dissolved concentrations was 
calculated (eq. 1) by multiplying the baseline average concentrations with dissolved fractions found in literature (Ingvertsen et al., 2011);

- $\quad$ Triple estimate, minimum concentration is zero (TE-0): $C_{\text {mean, } i}$ was calculated (eq. 1 ) where $C_{m i n, i}$ was assumed to be zero, which reflects the possibility that a pollutant may not be present in the runoff (i.e. below detection limits);

- $\quad$ Triple estimate, uncorrected maximum (TE-uncorr): $C_{\text {max }, i}$ was used instead of $C_{\text {max,corr, } i}$ to calculate $C_{\text {mean, } i}$ in eq. 2;

- Worst case, corrected maximum (WC-corr): The impacts were calculated using $C_{\text {max,corr, }}$ instead of $C_{\text {mean, }, \text {; }}$

- Worst case, uncorrected maximum (WC-uncorr): $C_{\text {max }, i}$ was used instead of $C_{\text {mean }, i .}$

Some of the classes of organic compounds showed large variation in CFs, e.g. CFs for pesticides were ranging between $9.3 \mathrm{E}+01$ and $1.2 \mathrm{E}+07 \mathrm{CTUe} / \mathrm{kg}$ emitted. To test the uncertainty connected to using the median CF, the maximum CF of each class was used instead in eq. 4.

\subsection{Importance of stormwater discharges}

The relative importance of urban stormwater discharges was evaluated by comparing the calculated impacts of stormwater pollutants with average anthropogenic impacts used for normalization in LCA (Laurent and Hauschild, 2015). Normalization references ideally cover all impacts caused by a single person over a year, taking into account all relevant processes (e.g. housing, consumption, transport). Additionally, impacts caused by urban stormwater discharges were compared to impacts of runoff from agricultural areas, which is considered to be a major contributor to eutrophication impacts.

\subsection{Legal screening}

The findings of the LCIA were cross-checked by comparing the concentration ranges of metals and organic compounds to the environmental quality standards (EQS) defined by European and Danish legislation (European Commission, 2013, 2008; Miljø- og Fødevareministeriet, 2016). This resembles the approach used in Johnson et al. (2017) to evaluate the risk of different chemicals in freshwater, where EQS were compared to median measured concentrations. To assess how often EQS might be exceeded by stormwater 
discharges, we calculated the frequency of exceedance $\left(f_{\text {exc }}\right)$, using the complete dataset of concentrations found in literature:

$$
f_{\text {exc }}=\frac{1}{N_{\text {obs }}} \sum_{i=1}^{N_{\text {obs }}} \alpha\left(C_{\text {rep }, i}\right) \quad \text { where } \alpha\left(C_{\text {rep }, i}\right)=\left\{\begin{array}{l}
0 \text { if } C_{\text {rep }, i} \leq M A C-E Q S \\
1 \text { if } C_{r e p, i}>M A C-E Q S
\end{array}\right.
$$

Where $N_{o b s}$ is the number of available data, and $C_{r e p, i}$ are reported concentrations. $f_{e x c}$ provides an estimation of how often the maximum allowed concentration (MAC-EQS) is expected to be exceeded based on available measurements. Chronic exposure to metals was evaluated by comparing average concentrations $\left(C_{\text {mean,i }}\right)$ against annual averages (AA-EQS). For organic compounds, no average concentrations could be calculated due to insufficient data (section 2.2), so all reported measurements were compared to the AAEQS. This evaluation provides a conservative evaluation based on a worst-case scenario, where dilution in the recipients is limited and/or the background concentration in the recipient is high. Furthermore, the comparison mainly aimed at evaluating the findings of the LCIA in terms of relative importance of the different pollutants to the overall negative impacts.

\section{Results and discussion}

\subsection{Concentration of stormwater pollutants}

In the selected publications, a total of 20 metals, almost 300 organic compounds, and nutrients were reported as potentially present in runoff. The number of concentration data points in literature per pollutant varied between 0 (no concentration data available) and 44, including minimum, maximum, and mean concentrations, either for single events, or as averages for several events or catchments. Between 4 and 32 measurements were available for metals. 21 measurements were found for total phosphorous, and 10 for total nitrogen. Concentration data was available for only $54 \%$ of the organic pollutants. Minimum, maximum, and mean concentrations for all pollutants are listed in SI.

The heterogeneity of the available measurements required significant efforts to calculate average concentrations, and a series of subjective choices had to be made (selection of key references, definition of outliers, and calculation of average values). These difficulties have been identified also in connection with 
surface water measurements by other researchers (Johnson et al., 2017). This strongly highlights the need for standardized and more comprehensive data reporting on water pollution. Figure 2 provides an overview of all the found measured concentration ranges. It should be stressed that the estimated average concentrations should be only used for evaluating the long-term environmental impacts of stormwater discharges. The evaluation of short-term impacts would require a bigger set of measurements, in order to have a better representation of the inter-event variability in concentration values.

The measured concentrations of total phosphorous ranged between $0.001 \mathrm{mg} / \mathrm{l}$ and $4.40 \mathrm{mg} / \mathrm{l}$, with a median concentration of $0.32 \mathrm{mg} / \mathrm{l}$. For total nitrogen, the concentrations ranged between $0.20 \mathrm{mg} / \mathrm{l}$ and 14.0 $\mathrm{mg} / \mathrm{l}$, with a median of $2.0 \mathrm{mg} / \mathrm{l}$.

Reported metal concentrations per litre of stormwater ranged from nanograms up to milligrams. Since references often did not specify if total or dissolved concentrations were reported, all data were incorporated first, i.e. it was assumed all reported values were stating dissolved concentration. An adjusted dissolved fraction was then analysed in the sensitivity analysis (TE-diss). The highest concentrations were reported for zinc $\left(C_{\max }\right.$ of $\left.22.5 \mathrm{mg} / \mathrm{l}\right)$ and lead $\left(C_{\max }\right.$ of $\left.14.5 \mathrm{mg} / \mathrm{l}\right)$, and both values were significantly higher than the determined best guess ( $\mathrm{C}_{\mathrm{Bg}}$ of $0.4 \mathrm{mg} / \mathrm{l}$, and $0.02 \mathrm{mg} / \mathrm{l}$ respectively). The absolute maximum $\left(C_{\max , i}\right)$ exceeded the best guess concentration $\left(C_{B G, i}\right)$ significantly for 17 metals, i.e. the corrected maximum was used (eq. 2). $C_{\text {mean, }}$ ranged between $0.1 \mu \mathrm{g} / \mathrm{l}(\mathrm{Hg})$ and $490 \mu \mathrm{g} / \mathrm{l}(\mathrm{Zn})$. The concentrations of metals where the maximum dissolved fraction was calculated based on solubility product constants were significantly lower than for the rest of the metals, with $0.1 \mu \mathrm{g} / \mathrm{l}$ for aluminium and $0.0003 \mathrm{ng} / \mathrm{l}$ for iron, reflecting the low solubility of these metals in water.

Observed concentrations of organic compounds all ranged in the $\mu \mathrm{g} / \mathrm{l}$ scale, with the highest concentrations reported for glyphosate $(232 \mu \mathrm{g} / \mathrm{l})$, phthalates (up to $32 \mu \mathrm{g} / \mathrm{l}$ ) and phenols (up to $12 \mu \mathrm{g} / \mathrm{l}$ ). A large fraction (75\%) of the organic compound concentrations were below $1 \mu \mathrm{g} / \mathrm{l}$ and one third was below $0.1 \mu \mathrm{g} / \mathrm{l}$. No concentration data were available for almost half of the compounds, and less than five concentrations were reported for more than $80 \%$ of the compounds with available data. This lack of data was accounted for by choosing a worst-case approach of using the maximum concentration for all compounds where data was available. 


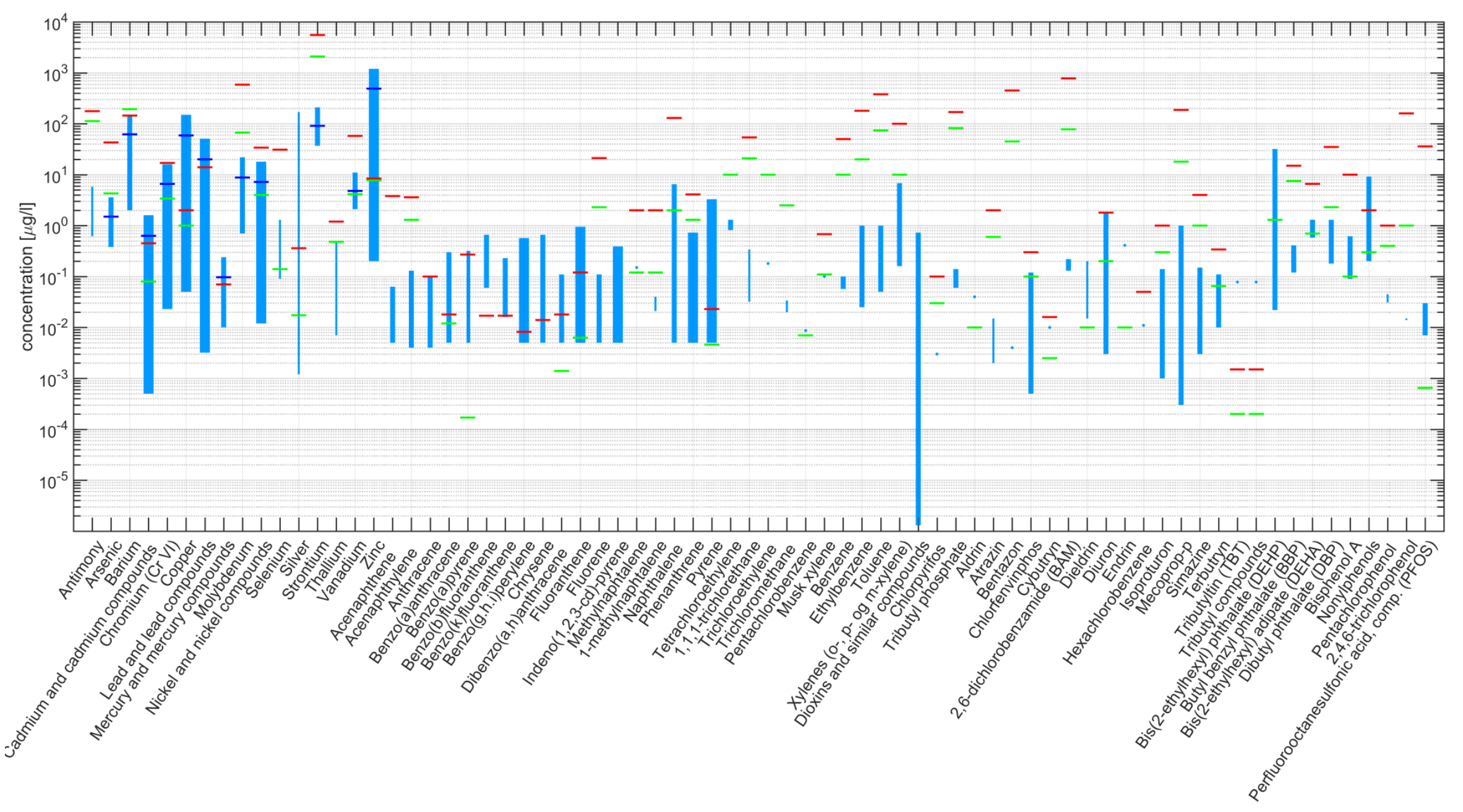

Figure 2. Concentration ranges for priority substance measured in separate stormwater systems (blue lines, expressed as minimum and uncorrected maximum value), AA-EQS (green lines) and MAC-EQS (red lines). The width of the blue line is proportional to the number $n$ of available measurements (thinnest line $n<5$, thickest line $n>20$ ), horizontal blue lines show $C_{\text {mean }}$ for metals. 


\subsection{Environmental impacts}

\subsubsection{Ecotoxicity impacts}

The potential freshwater ecotoxicity impact of runoff was calculated as $0.72 \mathrm{CTUe} / \mathrm{l}$ for untreated discharges to freshwater. This impact score was dominated by metals, which account for $97 \%$ (0.70CTUe/l) of the total score. Copper and zinc were the main contributors ( $81 \%$, and $9 \%$ respectively), while iron caused the lowest potential impacts (nine orders of magnitude lower than copper due to the low solubility of $\mathrm{Fe}(\mathrm{III})$ ). This is in line with a recent study stating that $\mathrm{Cu}$ and $\mathrm{Zn}$ account for $99 \%$ of the total freshwater ecotoxicity impacts of wet weather discharges (Risch et al., 2018). It also supports the conclusion that $\mathrm{Cu}$ and $\mathrm{Zn}$ and pose a significant threat to receiving freshwater environments (Johnson et al., 2017). Total potential marine ecotoxicity impacts were in the same order of magnitude as the freshwater ecotoxicity impact potential (0.82CTUe/l), with zinc being the largest contributor (94\%). Copper and zinc mainly stem from corrosion of metal structures in the catchment area (e.g. metallic roofs and drain pipes) and from wearing of vehicles (Chebbo et al., 2001; Ellis and Revitt, 2008). The impacts of all other substances were at least one (Pg, Mg), and up to five ( $\mathrm{Cr}$ ) orders of magnitude lower (Figure 4 and $\mathrm{SI}$ ). Copper caused significantly lower ecotoxicity impacts to marine water than to freshwater (9.7E-03, and 5.8E-01 CTUe/l respectively), because there are three orders of magnitude difference between the CFs for copper in freshwater and marine water $(3.6 \mathrm{E}+07$ CTUe/kg and 1.2E+04 CTUe/kg, respectively), reflecting that species living in freshwater are more affected than species in seawater (Dong et al., 2016; Rosenbaum et al., 2008).

Even with our method of utilizing maximum concentrations (section 2.2), organic compounds only accounted for $3 \%(0.02 \mathrm{CTUe} / \mathrm{l})$ of the freshwater ecotoxicity impacts. The groups accounting for most of the impacts caused by organic compounds were dioxins (1.2\%), pesticides (1.0\%) and polycyclic aromatic hydrocarbons $(0.7 \%)$ (Figure 3). Without marine CFs for organic compounds we can only speculate that metals would dominate the calculated ecotoxicity in marine environments as well. However, we do not expect a higher significance of organic compounds than in freshwater, since the impact pathways are similar in both environmental compartments. 
a) Freshwater ecotoxicity

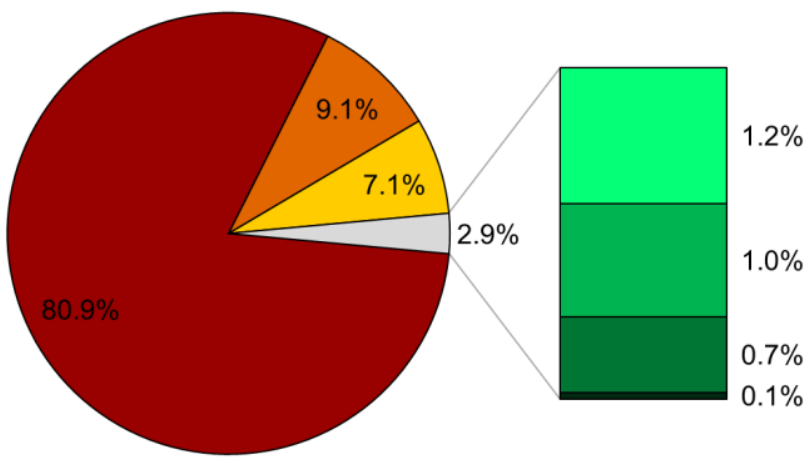

b) Marine ecotoxicity

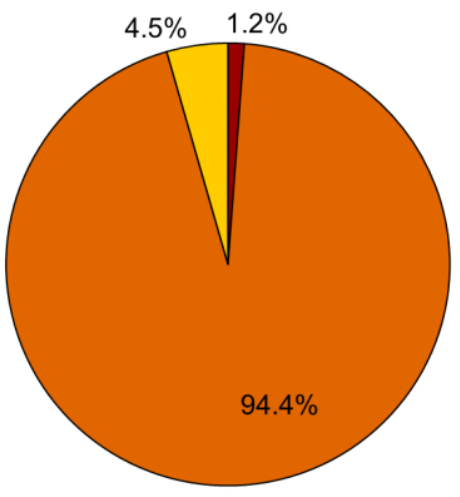

Metals:

Copper

Zinc

Other metals
Organic compounds:

Dioxins

Pesticides

PAHs

Other org. comp.

Figure 3. Relative potential ecotoxicity impacts of stormwater for a) metals and organic compounds discharged to freshwater; b) metals discharged to seawater

There is an ongoing discussion of whether the modelling of metal ecotoxicity in LCA potentially overestimates impacts stemming from emissions of metals. Metals occur in many different forms, and only the free ions form contributes to toxicity. The CFs have been corrected by Dong et al. (2014) to reflect the decreased bioavailable fraction but since the free ion form also has higher toxicity than the total metal, the resulting change in the CF is moderate for most metals. Metals are more persistent than organic substances, and this is reflected in the fate modelling that is used part of the characterisation modelling, contributing to a higher toxicity of metals. However, in the USEtox fate module, the residence time of freshwater is only 100 days and for coastal water bodies one year (Rosenbaum et al., 2008), which limits the influence of the long- 
term persistence of the metals on the characterisation factors. We thus consider the found dominance of metals in the overall ecotoxicity scores for stormwater discharges to be realistic.

The ecotoxicity potential of metals depends on the characteristics of the receiving water body. CFs for $\mathrm{Cu}$ have been found to differ within three orders of magnitude for different freshwater and marine archetypes, while CFs for $\mathrm{Zn}$ vary within one order of magnitude for freshwater and within two orders for marine water (Dong et al., 2016, 2014). We present generic toxicity potentials, but spatial differentiation has to be considered when applying the findings to a specific case study.

\subsubsection{Eutrophication impacts}

The average eutrophication impacts were $3.2 \mathrm{E}-07 \mathrm{kgP}-\mathrm{eq} / \mathrm{l}$ for freshwater and $2.0 \mathrm{E}-06 \mathrm{kgN}-\mathrm{eq} / \mathrm{l}$ for marine waters. Since the impacts directly correspond to the calculated concentrations and no CF was necessary, the uncertainty is lower than for ecotoxicity impacts. The relative importance of eutrophication impacts from stormwater discharges is discussed in section 3.4.

\subsubsection{Uncertainty analysis}

The uncertainty analysis showed the importance of differentiation between dissolved and total concentrations of metals, with twice as high freshwater ecotoxicity impacts for total concentrations (TE-diss, Figure 4). This supports the introduction of a bioavailability factor in the CFs to represent the truly dissolved fraction of metals (Gandhi et al., 2010). The dissolved concentration of copper depends heavily on the concentration of dissolved organic carbon in the water, which can be high e.g. in areas with extensive agriculture or in wastewater. Our calculations would overestimate the impact of copper in cases where high concentrations of dissolved organic carbon remove the dissolved copper from the bioavailable fraction.

The influence of the minimum and maximum values in the triple estimate approach was different: while setting $C_{m i n, i}$ to zero (TE-0) led to insignificant changes in impacts ( $<1 \%$ difference), using the uncorrected maximum (TE-uncorr) led to impacts 23 times higher than the baseline. Since a skewed normal distribution for the observed data is assumed in eq. 1 (Lichtenberg, 2000), this explains the importance of high values on $C_{\text {mean,i. }}$. The need for removing outlier concentrations was also shown by the worst case

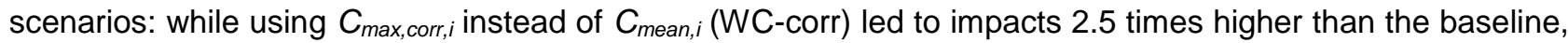


using the uncorrected maximum values $C_{\max , i}$ (WC-uncorr) led to a factor of 110 (Figure 4). This analysis underlines how concentrations measured close to pollutant sources (e.g. roof runoff from metallic roofs) or reflecting the natural variability of stormwater runoff (i.e. corresponding to extreme events) can lead to an overestimation of the average impacts from stormwater runoff.

Despite the increase in the absolute values of impacts, the relative importance of the different pollutants was similar for all scenarios: copper contributed most to freshwater ecotoxicity impacts (75-94\%), followed by zinc (4-10\%). Marine ecotoxicity impacts followed the same pattern of changes in total impacts for the five different scenarios, with Zinc being most contributing substance in all scenarios (SI).

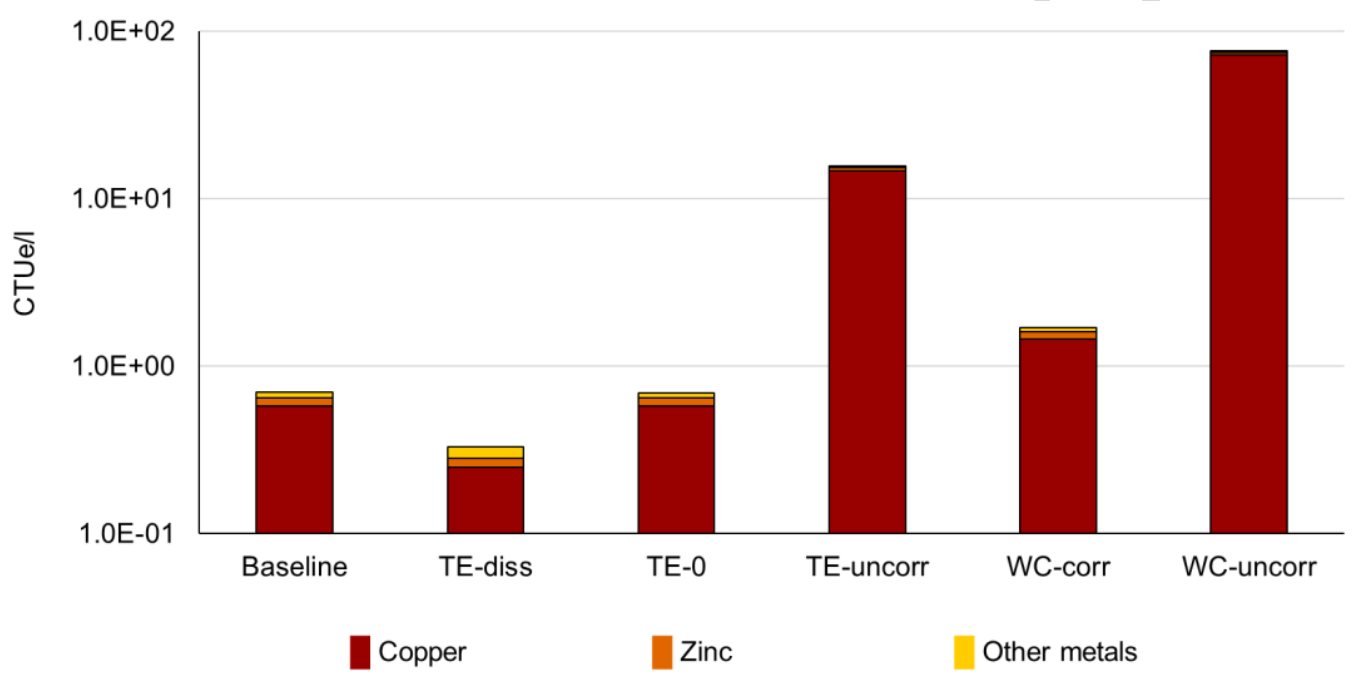

Figure 4. Freshwater ecotoxicity impacts for the different concentration scenarios described in section 2.5. Impacts are shown on a logarithmic scale.

When using the maximum CF instead of the median CF for substances without specific CF available, the freshwater ecotoxicity impacts of organic compounds were two orders of magnitude higher $(1.7 \mathrm{E}+00$ CTUe/l, compared to $2.1 \mathrm{E}-02 \mathrm{CTUe} / \mathrm{l})$, which is the same order of magnitude of the impacts of metals. The largest increases could be seen for unclassified organic compounds ( 5 orders of magnitude), and pesticides and hydrocarbons (2 orders of magnitude). This stems from the fact that CFs of highly toxic compounds were used to calculate the impacts of pollutants in the same class without CFs available that occurred in relatively high maximum concentrations. These highly toxic pollutants are often restricted or completely banned, e.g. in Denmark (Kjølholt et al., 2007), and only occur in very low concentrations (7.6E-03 $\mu \mathrm{g} / \mathrm{l}$ up to $4.1 \mathrm{E}-01 \mu \mathrm{g} / \mathrm{l})$. It is therefore expected that the tested approach is overestimating the potential impacts of organic pollutants. 


\subsection{Relative importance of impacts}

For freshwater ecotoxicity, the average impact per person per year in Europe has been estimated at 8940 CTUe (Sala et al., 2015). According to our findings, just $12 \mathrm{~m}^{3}$ of stormwater with the toxicity impacts of $0.72 \mathrm{CTUe} / \mathrm{l}$ has the same potential as the normalisation reference. In Denmark an average of $125 \mathrm{~m}^{2}$ impervious area per person is connected to a stormwater management system ( $75 \mathrm{~m}^{2}$ to a separate, and 50 $\mathrm{m}^{2}$ to a combined sewer system) (Ministry of Environment and Food DK, 2017). Assuming typical Danish conditions of an annual rainfall of $700 \mathrm{~mm}$ and $40 \%$ losses to evaporation and infiltration, $53 \mathrm{~m}^{3}$ of annual stormwater are generated from this area, which implies that the stormwater discharges alone are causing more ecotoxicity impacts per person than the average impact for all human activities estimated by Sala et al. (2015). This contradiction is potentially caused by an overestimation of the toxicity impacts. On the other hand, we suspect the normalisation reference to underestimate the actual impacts of human activities, since it does not take into account numerous emissions associated to human activities. Ecotoxicity pressure is potentially exerted by thousands of different substances released from industry, agriculture or households. Current normalisation references for ecotoxicity only gather information about a few hundred of these and not all of them are covered by CFs. The existing normalisation reference will therefore underestimate the true impacts of an average person by neglecting relevant activities (e.g. discharges of stormwater), but the magnitude of the underestimation is not obvious. A Danish study estimated an average annual freshwater ecotoxicity impact from human consumption which corresponds to 49020 CTUe (Kalbar et al., 2016), i.e. half an order of magnitude higher than the commonly used normalisation reference (Sala et al., 2015), and even this value does not cover the emissions from all relevant activities.

Pesticides are used more heavily in agricultural than in urban areas, and high levels of copper and zinc are measured in pig manure applied on farmland (Bak et al., 2015). However, pollutants are to a large degree retained in soil and are not expected to reach water bodies before they degrade (organic compounds) or become immobilized (metals). This is in line with a German study naming urban runoff as the main source for $\mathrm{Cu}, \mathrm{Zn}$, and PAHs in surface waters (German Environment Agency, 2017).

We found stormwater discharges to have limited eutrophication impacts compared to other activities, including agriculture. Assuming an urban area of $125 \mathrm{~m}^{2}$ per person, the impacts from stormwater discharges account for only $1.1 \%$ of the average annual freshwater eutrophication impact per person, and $0.6 \%$ for 
marine eutrophication (Sala et al., 2015). Using a median nitrogen concentration of $2 \mathrm{mg} / \mathrm{l}$, an annual mass flow of $8.4 \mathrm{kgN} / \mathrm{ha}$.yr was expected from stormwater from urban areas. This is in the same order of magnitude of the relative nutrient release from agricultural areas. Between 10 and $17 \mathrm{kgN} / \mathrm{ha}$.yr were estimated to be discharged to surface water bodies from agricultural areas in Denmark, depending on the soil type (Jensen et al., 2016). However, urban areas cover a limited area compared to agricultural areas, thus contributing less to runoff discharges. This is backed by the findings of the German Environment Agency, who showed that $75 \%$ of nitrogen, and $50 \%$ of phosphorous found in German surface waters stem from agriculture (German Environment Agency, 2017).

We assume that the variations in stormwater pollution are mainly driven by differences in land usage rather than in geographical location. Although the absolute impacts might change, we expect the relative importance of the various pollutants to be similar also for areas that were not included in the analysis. Therefore, we expect metals to be the main contributors to ecotoxicity impacts also outside Europe and North America. The representativeness of the analysed data might be affected due to e.g. source control policies as for banning of lead in gasoline, which limits the usage of data collected in previous decades (cf. Park et al., 2009).

\subsection{Legal screening}

Comparing measured stormwater pollutant concentrations against EQS clearly identified metals as problematic, which is in line with the findings from the LCIA. The EQS for most metals laid within the range of reported concentrations, except for strontium and molybdenum with concentrations never exceeding EQS (Figure 2). The highest $f_{e x c}$ was calculated for $\mathrm{Cu}(78 \%)$ and $\mathrm{Zn}(84 \%)$, which have also been identified as causing the highest impacts. Additionally, $C_{\text {mean, } i}$ exceeded the EQS for several orders of magnitude (one for $\mathrm{Cu}$ and two for $\mathrm{Zn}$ ). Other problematic substances were $\mathrm{Ba}, \mathrm{Pb}, \mathrm{Hg}$, and $\mathrm{TI}$, with approximately half of the reported values exceeding the MAC-EQS (Figure 2). $C_{\text {mean,i }}$ exceeded AA-EQS with at least one order of magnitude for five metals $(\mathrm{Ag}, \mathrm{Ca}, \mathrm{Cu}, \mathrm{Pb}, \mathrm{Zn})$, were in same order of magnitude for seven $(\mathrm{As}, \mathrm{Ba}, \mathrm{Cr}, \mathrm{Ni}$, Se, TI, Va), and at least one order below for four (An, Cd, Mg, Mo, Sr). No EQS were available for four metals ( $\mathrm{Al}, \mathrm{Be}, \mathrm{Fe}, \mathrm{Hg})$. 
Most organic pollutants either complied with EQS, or no EQS are defined. Within organic pollutants, PAHs were the most problematic class from a legal perspective, with $f_{e x c}$ above $50 \%$ for seven pollutants. This is in line with the LCIA, where PAHs, together with dioxins and pesticides, caused the highest impacts. Findings in literature show similar results, stating that PAHs cause a significant hazard, but finding a higher importance of pesticides and phenols when comparing measured to predicted no-effect concentrations (Gosset et al., 2017). Contrary to that, we only identified single pesticides, phthalates and phenols as critical when comparing to EQS. All eight reported concentrations of benzo[b]fluoranthene exceeded the MAC-EQS (i.e. $f_{e x c}=100 \%$ ). Nonylphenol had a $f_{e x c}$ of $67 \%$ (14 reported concentrations), and tributyltin and pentachlorophenol of $20 \%$ (four, and three reported concentrations respectively). All other organic compounds complied with available MAC-EQS (Figure 3). Reported concentrations exceeded AA-EQS for more than $50 \%$ of the available data for seven PAHs (benzo[a]anthracene, benzo[a]pyrene, chrysene, dibenzo[ah]anthracene, fluoranthene, methylnaphthalene, pyrene), one other hydrocarbon (pentachlorobenzene), two pesticides (cybutryne, dieldrin), one phthalate (DEHP), two phenols (bisphenol A, nonylphenol), and perfluorooctanesulfonic acid. On average, 12 concentrations were reported for these pollutants, which is significantly more than the average of all organic compounds ( 3 concentrations). Additionally, EQS are not defined for a great part of the organic micropollutants (Figure 5). This highlights how the proposed approach is valid only for priority pollutants, i.e. pollutants that have already been identified by legislation. This finding also applies to LCIA, were characterisation factors are not available for all organic pollutants potentially present in stormwater. 


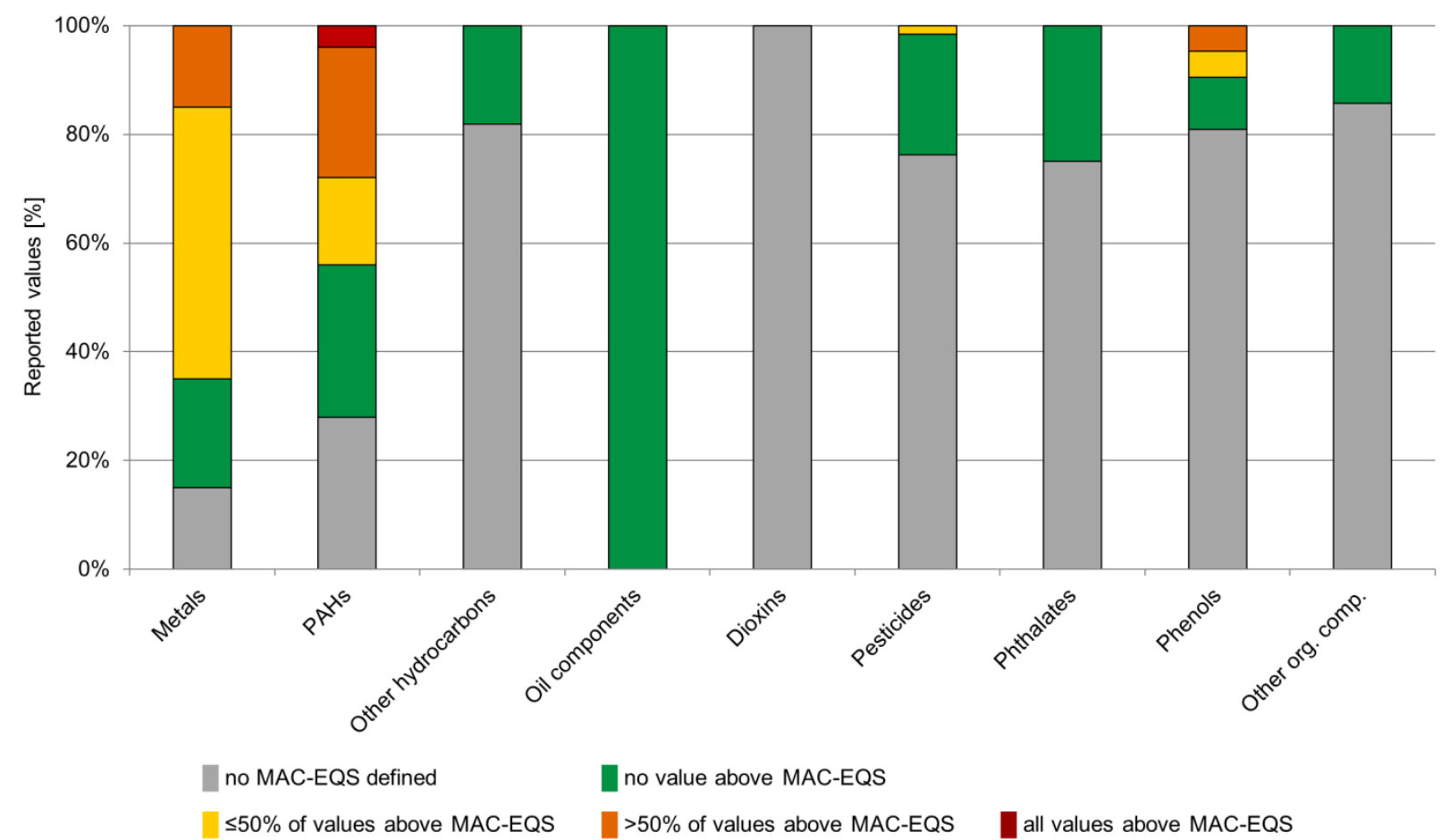

Figure 5. Frequency of exceedance of reported concentration compared with maximum allowed concentration environmental quality standard (MAC-EQS) for metals and organic compounds.

\section{Conclusions}

Significant manual corrections and assumptions were necessary when calculating mean pollutant concentrations in stormwater due to very heterogeneous ways of analysing and reporting values in literature. Standardized and comprehensive data and measurements of organic compounds are very limited.

Average concentrations of metals ranged between $0.1 \mu \mathrm{g} / \mathrm{l}(\mathrm{Hg})$ and $490 \mu \mathrm{g} / \mathrm{l}(\mathrm{Zn})$. Maximum concentrations of organic compounds of up to $232 \mu \mathrm{g} / \mathrm{l}$ (Glyphosate) were reported in literature, while $75 \%$ of the reported concentrations were below $1 \mu \mathrm{g} / \mathrm{l}$. The median concentrations of total phosphorous and nitrogen were $0.32 \mathrm{mg} / \mathrm{l}$, and $2.0 \mathrm{mg} / \mathrm{l}$ respectively.

Using LCIA, the total ecotoxicity impact of stormwater discharges to freshwater were calculated as $0.72 \mathrm{CTUe} / \mathrm{l}$, and $0.82 \mathrm{CTUe} / \mathrm{l}$ for discharges to the sea. Eutrophication impacts were $3.2 \mathrm{E}-07 \mathrm{kgP}-\mathrm{eq} / \mathrm{l}$ for freshwater, and 2.0E-06 kgN-eq/l for marine waters. 
Metals were clearly identified as the main contributor to ecotoxicity impacts, with zinc and copper contributing more than $90 \%$ of the total freshwater and marine impacts. This highlights the potential for impact reduction through source control, e.g. through regulation of the use of $\mathrm{Cu}$ and $\mathrm{Zn}$ in vehicles and as building materials and promotion of available alternatives, and the need for stormwater treatment aimed at removing metals.

Ecotoxicity impacts from urban stormwater showed a high significance when comparing to impacts from other pollutant sources, i.e. consumption and agricultural processes. In contrary, eutrophication impacts from stormwater were found less significant.

Metals, especially copper and zinc, were identified as most problematic when comparing the collected concentration data of pollutants to existing EQS, supporting the conclusions drawn from the LCIA. Both LCIA and EQS did not cover all pollutants potentially present in runoff, which in combination with limited concentration data availability highlights the need for further research in assessing long-term environmental impacts of stormwater discharges.

\section{Acknowledgements}

The Ministry of Science, Technology and Innovation in Denmark and VCS Denmark, HOFOR and Aarhus Vand funded the Industrial PhD project on which Sarah Brudler is employed. The Danish EPA funded part of this research under contract 33010-NIFA-16-641.

\section{Supporting Information}

Detailed concentration data and results of the life cycle impact assessment and legal screening for individual pollutants (metals, organic compounds, and nutrients).

\section{References}

Arnbjerg-Nielsen, K., Hvitved-Jacobsen, T., Ledin, A., Auffarth, K., Mikkelsen, P.S., Baun, A., Kjølholt, J., 
2002. Processing of measurements of rain-induced emissions of NPO and environmentally hazardous substances from common systems (Bearbejdning af målinger af regnbetingede udledninger af Npo og miljøfremmede stoffer fra fællessystemer i forbindelse med NOVA 2003). Copenhagen, Denmark.

Arnbjerg-Nielsen, K., Johansen, N.B., Schlütter, F., Kaasgaard, M., Rauch, W., Mikkelsen, P.S., 1999. Urban pollution runoff modelling from combined sewer overflows, in: Proceedings of the 8th International Conference on Urban Storm Drainage, Sydney, Australia, August 30 - September 3. The Institution of Engineers Australia, Sydney, pp. 357-364.

Asman, W.A.H., Jørgensen, A., Bossi, R., Vejrup, K. V., Bügel Mogensen, B., Glasius, M., 2005. Wet deposition of pesticides and nitrophenols at two sites in Denmark: Measurements and contributions $\begin{array}{lllll}\text { from } & \text { regional } & \text { sources. } & \text { Chemosphere } & 59,\end{array}$ https://doi.org/10.1016/j.chemosphere.2004.11.048

Bak, J.L., Jensen, J., Larsen, M.M., 2015. Evaluation of copper and zinc content in soil - Concentration and development in the grid and measurement in selected area types (Belysning af kobber- og zinkindholdet i jord - Indhold og udvikling i kvadratnettet og måling på udvalgte brugstyper).

Becouze-Lareure, C., Dembélé, A., Coquery, M., Cren-Olivé, C., Barillon, B., Bertrand-Krajewski, J.-L., 2016. Source characterisation and loads of metals and pesticides in urban wet weather discharges. Urban Water J. 13, 600-617. https://doi.org/10.1080/1573062X.2015.1011670

Bertrand-Krajewski, J.-L., 2007. Stormwater pollutant loads modelling: epistemological aspects and case studies on the influence of field data sets on calibration and verification. Water Sci. Technol. 55, 1. https://doi.org/10.2166/wst.2007.090

Bertrand-Krajewski, J.L., Barraud, S., Bardin, J.-P., 2002. Uncertainties, performance indicators and decision aid applied to stormwater facilities. Urban Water 4, 163-179.

Birch, H., Mikkelsen, P.S., Jensen, J.K., Holten Lützhøft, H.C., 2011. Micropollutants in stormwater runoff and combined sewer overflow in the Copenhagen area, Denmark. Water Sci. Technol. 64, 485-493. https://doi.org/10.2166/wst.2011.687

Brudler, S., Arnbjerg-Nielsen, K., Hauschild, M.Z., Rygaard, M., 2016. Life cycle assessment of stormwater 
management in the context of climate change adaptation. Water Res. 106, 394-404. https://doi.org/10.1016/j.watres.2016.10.024

Brudler, S. Arnbjerg-Nielsen, K., Hauschild, M.Z., Ammitsøe, C., Hénonin, J. Rygaard, M., 2018. Life cycle assessment of point source emissions and infrastructure impacts of four types of urban stormwater systems. Submitted.

Campbell, P.G.C., 1995. Interactions between Trace Metals and Aquatic Organisms: A Critique of the Freeion Activity Model, in: Tessier, A., Turner, D.R. (Eds.), Metal Speciation and Bioavailability in Aquatic Systems. pp. 45-102.

Chebbo, G., Gromaire, M.C., Ahyerre, M., Garnaud, S., 2001. Production and transport of urban wet weather pollution in combined sewer systems: the "Marais" experimental urban catchment in Paris. Urban Water 3, 3-15.

Clara, M., Windhofer, G., Hartl, W., Braun, K., Simon, M., Gans, O., Scheffknecht, C., Chovanec, A., 2010. Occurrence of phthalates in surface runoff, untreated and treated wastewater and fate during $\begin{array}{llll}\text { wastewater } \quad \text { treatment. } & \text { Chemosphere } & \text { 78, }\end{array}$ https://doi.org/10.1016/j.chemosphere.2009.12.052

Clauson-Kaas, J., Pedersen, B.M., Skov, J., Joensen, S.D., 2016. Copenhagen: Rainwater quality and handling of urban run-off, in: NOVATECH 2016. pp. 1-6.

Danish Nature Agency, 2016. The national program for monitoring of the aquatic ennvironment and nature (NOVANA - Det nationale program for overvågning af vandmiljø og natur).

De Sousa, M.R.C., Montalto, F. a., Spatari, S., 2012. Using Life Cycle Assessment to Evaluate Green and Grey Combined Sewer Overflow Control Strategies. J. Ind. Ecol. 16, 901-913. https://doi.org/0.1111/j.1530-9290.2012.00534.x

Diamond, M.L., Gandhi, N., Adams, W.J., Atherton, J., Bhavsar, S.P., Bulle, C., Campbell, P.G.C., Dubreuil, A., Fairbrother, A., Farley, K., Green, A., Guinee, J., Hauschild, M.Z., Huijbregts, M.A.J., Humbert, S., Jensen, K.S., Jolliet, O., Margni, M., McGeer, J.C., Peijnenburg, W.J.G.M., Rosenbaum, R., Van De Meent, D., Vijver, M.G., 2010. The clearwater consensus: The estimation of metal hazard in fresh 
water. Int. J. Life Cycle Assess. 15, 143-147. https://doi.org/10.1007/s11367-009-0140-2

Dong, Y., Gandhi, N., Hauschild, M.Z., 2014. Development of Comparative Toxicity Potentials of 14 cationic metals in freshwater. Chemosphere 112, 26-33. https://doi.org/10.1016/j.chemosphere.2014.03.046

Dong, Y., Rosenbaum, R.K., Hauschild, M.Z., 2017. Metal toxicity characterization factors for marine ecosystems-considering the importance of the estuary for freshwater emissions. Int. J. Life Cycle Assess. 1-13. https://doi.org/10.1007/s11367-017-1376-x

Dong, Y., Rosenbaum, R.K., Hauschild, M.Z., 2016. Assessment of Metal Toxicity in Marine Ecosystems: Comparative Toxicity Potentials for Nine Cationic Metals in Coastal Seawater. Environ. Sci. Technol. 50, 269-278. https://doi.org/10.1021/acs.est.5b01625

Ellis, J. B., Revitt, M.D., 2008. Quantifying Diffuse Pollution Sources and Loads for Environmental Quality Standards in Urban Catchments. Water Air Soil Pollut: Focus 8, 577-585.

Environmental Protection Agency Denmark, 2006. Measurements of pollutant levels in rain-induced overflows (Målinger af forureningsindhold i regnbetingede udledninger). Report no. 10. Copenhagen, Denmark. https://doi.org/87-7052-029-1

Eriksson, E., Baun, A., Mikkelsen, P.S., Ledin, A., 2005. Chemical hazard identification and assessment tool for evaluation of stormwater priority pollutants. Water Science and Technology 51, 47-55.

Eriksson, E., Baun, A., Mikkelsen, P.S., Ledin, A., 2007. Risk assessment of xenobiotics in stormwater discharged to Harrestrup Å, Denmark. Desalination 215, 187-197.

European Commission, 2013. Directive 2013/39/EU of the European Parliament and of the Council of 12 August 2013 amending Directives 2000/60/EC and 2008/105/EC as regards priority substances in the field of water policy.

European Commission, 2008. Directive 2008/105/EC of the European Parliament and of the Council of 16 December 2008 on environmental quality standards in the field of water policy, amending and subsequently repealing Council Directives 82/176/EEC, 83/513/EEC, 84/156/EEC, 84/491/EEC,.

European Commission, 2002. Pollution from Roads and Vehicles and Dispersal to the Local Environment: 
Final Report and Handbook Status: Confidential Pollution of Groundwater and Soil by Road and Traffic Sources : dispersal mechanisms, pathways and mitigation measur.

European Commission, 2000. DIRECTIVE 2000/60/EC OF THE EUROPEAN PARLIAMENT AND OF THE COUNCIL of 23 October 2000 establishing a framework for Community action in the field of water policy. Off. J. Eur. Communities L 269, 1-93. https://doi.org/2004R0726 - v.7 of 05.06.2013

Fletcher, T.D., Shuster, W., Hunt, W.F., Ashley, R., Butler, D., Arthur, S., Trowsdale, S., Barraud, S., Semadeni-Davies, A., Bertrand-Krajewski, J.-L., Mikkelsen, P.S., Rivard, G., Uhl, M., Dagenais, D., Viklander, M., 2014. SUDS, LID, BMPs, WSUD and more - The evolution and application of terminology surrounding urban drainage. Urban Water J. 9006. https://doi.org/10.1080/1573062X.2014.916314

Gandhi, N., Diamond, M.L., Van De Meent, D., Huijbregts, M.A.J., Peijnenburg, W.J.G.M., Guinée, J., 2010. New method for calculating comparative toxicity potential of cationic metals in freshwater: Application to Copper, Nickel, and Zinc. Environ. Sci. Technol. 44, 5195-5201. https://doi.org/10.1021/es903317a

Gasperi, J., Sebastian, C., Ruban, V., Delamain, M., Percot, S., Wiest, L., Mirande, C., Caupos, E., Demare, D., Kessoo, M.D.K., Saad, M., Schwartz, J.J., Dubois, P., Fratta, C., Wolff, H., Moilleron, R., Chebbo, G., Cren, C., Millet, M., Barraud, S., Gromaire, M.C., 2014a. Micropollutants in urban stormwater: Occurrence, concentrations, and atmospheric contributions for a wide range of contaminants in three French catchments. Environ. Sci. Pollut. Res. 21, 5267-5281. https://doi.org/10.1007/s11356-0132396-0

Gasperi, J., Sebastian, C., Ruban, V., Delamain, M., Percot, S., Wiest, L., Mirande, C., Caupos, E., Demare, D., Kessoo, M.D.K., Saad, M., Schwartz, J.J., Dubois, P., Fratta, C., Wolff, H., Moilleron, R., Chebbo, G., Cren, C., Millet, M., Barraud, S., Gromaire, M.C., 2014b. Micropollutants in urban stormwater: Occurrence, concentrations, and atmospheric contributions for a wide range of contaminants in three French catchments. Environ. Sci. Pollut. Res. 21, 5267-5281. https://doi.org/10.1007/s11356-0132396-0

German Environment Agency, 2017. Waters in Germany:- Status and assessment. 
GEUS, n.d. National Geophysical Database Denmark (GERDA).

Gosset, A., Durrieu, C., Orias, E., Bayard, E., Perrodin, Y., 2017. Identification and assessment of ecotoxicological hazards attributable to pollutants in urban wet weather discharges. Environ. Sci. Process. Impacts 19. https://doi.org/10.1039/c7em00159b

Göbel, P., Dierkes, C., Coldewey, W.G., 2007. Storm water runoff concentration matrix for urban areas. J. Contam. Hydrol. 91, 26-42.

Henderson, A., 2015. Eutrophication. Chapter 10, in: Hauschild, M.Z., Huijbregts, M.A.J. (Eds.), Life Cycle Impact Assessment. LCA Compendium - The Complete World of Life Cycle Assessment. Springer Press.

Henderson, A.D., Hauschild, M.Z., Van De Meent, D., Huijbregts, M. a J., Larsen, H.F., Margni, M., McKone, T.E., Payet, J., Rosenbaum, R.K., Jolliet, O., 2011. USEtox fate and ecotoxicity factors for comparative assessment of toxic emissions in life cycle analysis: Sensitivity to key chemical properties. Int. J. Life Cycle Assess. 16, 701-709. https://doi.org/10.1007/s11367-011-0294-6

IEC, 2009. IEC 31010:2009 - Risk management -- Risk assessment techniques.

Ingvertsen, S.T., Jensen, M.B., Magid, J., 2011. A minimum data set of water quality parameters to assess and compare treatment efficiency of stormwater facilities. J. Environ. Qual. 40, 1488-1502. https://doi.org/10.2134/jeq2010.0420

ISO, 2006a. Environmental Management - Life Cycle Assessment - Requirements and guidelines - ISO 14044, ISO 14040:2006. Brussels, Belgium.

ISO, 2006b. Environmental Management - Life Cycle Assessment - Principles and framework - ISO 14044, ISO 14044:2006. Brussels, Belgium.

Jensen, P.N., Boutrup, S., Freshavn, J.R., Svendsen, L.M., Blicher-Mathiesen, G., Thodsen, H., Johansson, L.S., Hansen, J.W., Nygaard, B., Søgaard, B., Holm, T.E., Ellermann, T., Thorling, L., Holm, A.G., 2016. Aquatic environment and nature 2015 (Vandmiljø og Natur 2015), Nationalt Center for Miljø og Energi. 
Johnson, A.C., Donnachie, R.L., Sumpter, J.P., Jürgens, M.D., Moeckel, C., Pereira, M.G., 2017. An alternative approach to risk rank chemicals on the threat they pose to the aquatic environment. Sci. Total Environ. 599-600, 1372-1381. https://doi.org/10.1016/j.scitotenv.2017.05.039

Kalbar, P.P., Birkved, M., Kabins, S., Nygaard, S.E., 2016. Personal Metabolism (PM) coupled with Life Cycle Assessment (LCA) model: Danish Case Study. Environ. Int. 91, 168-179. https://doi.org/10.1016/j.envint.2016.02.032

Kayhanian, M., Suverkropp, C., Ruby, A., Tsay, K., 2007. Characterization and prediction of highway runoff constituent event mean concentration. J. Environ. Manage. 85, 279-295. https://doi.org/10.1016/j.jenvman.2006.09.024

Kjøholt, J., Poll, C., Jensen, F.K., 1997. Environmentally hazardous substances in surface runoff from sealed areas (Miljøfremmede stoffer i overfladeafstrømning fra befæstede arealer).

Kjølholt, J., Stuer-Lauridsen, F., Baun, A., Arnbjerg-Nielsen, K., 2001. Biological effects of toxic compounds in rain-induced overflows (Biologiske effekter af toksiske stoffer i regnbetingede udløb).

Kjølholt, J., Vigsø, D., Arnbjerg-Nielsen, K., Hansen, E., Ringgaard, K.W., Rasmussen, P.E., 2007. Possible Control of EU Priority Substances in Danish Waters - Technical and economic consequences examined by three scenarios.

Laurent, A., Hauschild, M.Z., 2015. Normalisation, in: Hauschild, M.Z., Huijbregts, M.A.J. (Eds.), Life Cycle Impact Assessment. LCA Compendium - The Complete World of Life Cycle Assessment. Springer Press, pp. 271-300. https://doi.org/10.1007/978-94-017-9744-3_14

Ledin, A., Auffarth, K.P.S., Boe-Hansen, R., Eriksson, E., Albrechtsen, H.-J., Baun, A., Mikkelsen, P.S., 2004. Use of runoff from roofs and impermeable areas (Brug af regnvand opsamlet fra tage og befæstede arealer).

Lichtenberg, S., 2000. Proactive Management of Uncertainty using the Successive Principle - a practical way to manage opportunities and risks, 1st ed. Polyteknisk Press, Copenhagen.

Loubet, P., Roux, P., Bellon-Maurel, V., 2015. WaLA, a versatile model for the life cycle assessment of urban 
water systems: formalism and framework for a modular approach. Water Res. Submitted. https://doi.org/10.1016/j.watres.2015.09.034

Lützhøft, H.H., Birch, H., Eriksson, E., Mikkelsen, P.S., 2011. Comparing chemical analysis with literature studies to identify micropollutants in a catchment of Copenhagen (DK), in: 12th International Conference on Urban Drainage. pp. 11-16

Madsen, K.B., Nielsen, U., 2008. Charaterisation of rainwater outflows in Hvidovre municipality (Undersøgelse af regnvandsudløb i Hvidovre Kommune).

Métadier, M., Bertrand-Krajewski, J.L., 2012. The use of long-term on-line turbidity measurements for the calculation of urban stormwater pollutant concentrations, loads, pollutographs and intra-event fluxes. Water Res. 46, 6836-6856.

Miljø- og Fødevareministeriet, 2016. Report on the establishment of environmental targets for streams, lakes, estuaries, coastal waters and groundwater (Bekendtgørelse om fastlæggelse af miljømål for vandløb, søer, overgangsvande, kystvande og grundvand), BEK 439.

Ministry of Environment and Food DK, 2017. Point sources 2015 (Punktkilder 2015).

Näf, C., Broman, D., Ishaq, R., Zebühr, Y., 1990. PCDDs and PCDFs in water, sludge and air samples from various levels in a waste water treatment plant with respect to composition changes and total flux. Chemosphere 20, 1503-1510.

Park, M.H., Swamikannu, X., Stenstrom, M.K., 2009. Accuracy and precision of the volume-concentration method for urban stormwater modeling. Water Research,. 43, 2773-2786.

Pedersen, B.M., 2013. Utilization of road runoff in the Århusgade neighborhood - Characterisation and modeling of road runoff and testing of selected treatment technologies (Nyttiggørelse af vejvand i Århusgadekvarteret - Karakterisering og modellering af vejvandsafledninger s.

Pedersen, B.M., Madsen, K.B., Nielsen, U., 2009. Characterisation of rainwater at Høje Gladsaxe - Overview of technologies for treatment of rainwater (Karakterisering af regnvand ved Høje Gladsaxe - Oversigt over teknologier til rensning af regnvand). Gladsaxe, Denmark.

Petersen, M.F., Clausen, L., Sølling, J., Vezzaro, L., Eriksson, E., Mikkelsen, P.S., 2013. Runoff from roofs 
and impermeable areas - risk assessment for groundwater pollution (Afstrømning fra tagflader og befæstede arealer - Vurdering af forureningsrisici for grundvand).

Pohl, J., Örn, S., Norrgren, L., Carlsson, G., 2015. Toxicological evaluation of water from stormwater ponds using Xenopus tropicalis embryos. Wetl. Ecol. Manag. 23, 1091-1098. https://doi.org/10.1007/s11273015-9444-0

Risch, E., Gasperi, J., Gromaire, M.C., Chebbo, G., Azimi, S., Rocher, V., Roux, P., Rosenbaum, R.K., Sinfort, C., 2018. Impacts from urban water systems on receiving waters - How to account for severe wet-weather events in LCA? Water Res. 128, 412-423. https://doi.org/10.1016/j.watres.2017.10.039

Rosenbaum, R.K., Bachmann, T.M., Gold, L.S., Huijbregts, M.A.J., Jolliet, O., Juraske, R., Koehler, A., Larsen, H.F., MacLeod, M., Margni, M., McKone, T.E., Payet, J., Schuhmacher, M., Van De Meent, D., Hauschild, M.Z., 2008. USEtox - The UNEP-SETAC toxicity model: Recommended characterisation factors for human toxicity and freshwater ecotoxicity in life cycle impact assessment. Int. J. Life Cycle Assess. 13, 532-546. https://doi.org/10.1007/s11367-008-0038-4

Sala, S., Benini, L., Mancini, L., Pant, R., 2015. Integrated assessment of environmental impact of Europe in 2010: data sources and extrapolation strategies for calculating normalisation factors 1568-1585. https://doi.org/10.1007/s11367-015-0958-8

Sebastian, C., 2013. Urban stormwater retention basins: removal efficiency for micropollutant (Bassin de retenue des eaux pluviales en milieu urbain: performance en matière de piégeage des micropolluants). National Institute of Applied Sciences of Lyon.

Spatari, S., Yu, Z., Montalto, F.A., 2011. Life cycle implications of urban green infrastructure. Environ. Pollut. 159, 2174-2179. https://doi.org/10.1016/j.envpol.2011.01.015

Tang, J.Y.M., Aryal, R., Deletic, A., Gernjak, W., Glenn, E., McCarthy, D., Escher, B.I., 2013. Toxicity characterization of urban stormwater with bioanalytical tools. Water Res. 47, 5594-5606. https://doi.org/10.1016/j.watres.2013.06.037

US EPA, 2015. The National Stormwater Quality Database Version 4.02 [WWW Document]. URL http://www.bmpdatabase.org/nsqd.html 
Van Buren, M.A., Watt, W.E.E., Marsalek, J., VanBuren, M.A., Watt, W.E.E., Marsalek, J., 1997. Application of the log-normal and normal distributions to stormwater quality parameters. Water Res. 31, 95-104. https://doi.org/10.1016/S0043-1354(96)00246-1

Wenning, R.J., Mathur, D.B., Paustenbach, D.J., Stephenson, M.J., Folwarkow, S., Luksemburg, W.J., 1999. Polychlorinated Dibenzo-p-Dioxins and Dibenzofurans in Storm Water Outfalls Adjacent to Urban Areas and Petroleum Refineries in San Francisco Bay, California. Arch. Environ. Contam. adn Toxicol. 290301.

Wicke, D., Matzinger, A., Rouault, P., 2015. Relevance of organic substances in runoff in Berlin (Relevanz organischer Spurenstoffe im Regenwasserabfluss Berlins - OgRE)

Wium-Andersen, T., Nielsen, A.H., Hvitved-Jakobsen, T., Vollertsen, J., 2011. Heavy metals, PAHs and toxicity in stormwater wet detention ponds. Water Sci. Technol. 64, 503-511.

Zgheib, S., Moilleron, R., Chebbo, G., 2012. Priority pollutants in urban stormwater: Part 1 - Case of separate storm sewers. Water Res. 46, 6683-6692. https://doi.org/10.1016/j.watres.2011.12.012

Ørestad, n.d. Water in Ørestad: analysis results from stations 1 to 15 (Vandlauget i Ørestad: Analyseresultater fra stationerne 1-15), in: Regnkvalitet 1.0, DHI, 2014). 